Check for updates

Berlin, Germany

Cite this as: BMJ 2021;372:n619 http://dx.doi.org/10.1136/bmj.n619 Published: 03 March 2021

\section{Covid-19: Germany struggles with slow uptake of Oxford AstraZeneca vaccine}

\author{
Hristio Boytchev
}

Germany is experiencing a slow uptake of the Oxford AstraZeneca covid-19 vaccine, latest figures show. Data up to 1 March show that of the 1452 ooo doses delivered to the country, a little over a third, (514 426) had been used. ${ }^{1}$

The slow uptake follows the decision by Germany's Standing Committee on Vaccination (STIKO) to limit the use of the vaccine to 18 to 64 year olds, based on a lack of sufficient data for over 65 s. Its decision is in line with other European countries, as the European Medical Agency recommended approval for all age groups, but at the same time gave a warning for those aged over 55. Austria, Denmark, France, the Netherlands, Norway, Poland, Spain, and Sweden only recommend it for people under 65 , and Belgium and Italy for those under 55 .

In Germany, the recommendation has slowed down the country's vaccination programme. The German government is currently giving priority to people aged 80 and over or in nursing homes-who cannot receive the Oxford vaccine because of their age-and people at high risk of infection because of their profession, primarily medical staff. A large part of that professional group, however, has received a vaccine already (2.9 million doses).

The Oxford vaccine has also become unpopular among medical staff who have not yet been vaccinated, following STIKO’s restricted recommendation and misleading reports ${ }^{2}$ of extremely low efficacy in the elderly. Doubts about the vaccine were repeated by high ranking professionals. The German Press Agency ${ }^{3}$ quoted the chairman of the World Medical Association and former president of the German Medical Association Frank Ulrich Montgomery saying that medical staff should not be vaccinated with the Oxford vaccine. "The lower effectiveness cannot be explained away," he said, adding that medical staff should be vaccinated "with better performing vaccines."

In an interview on public television ${ }^{4}$ on 27 February STIKO head Thomas Mertens said of STIKO's recommendations and their aftermath that "the whole thing has somehow gone badly."

"We never criticised the vaccine, we only said that the data were not good or not sufficient for over $65 \mathrm{~s}$," Mertens said. He said that the Oxford vaccine was "very good" and is "also getting better in terms of assessment with new data." He said that STIKO would be releasing a new, updated recommendation "very soon."

Wolf Dieter Ludwig, president of the Drug Commission of the German Medical Association, told The BMJ that STIKO had restricted the Oxford vaccine to the young "without convincing reason," since the
mRNA vaccines also underrepresented the elderly in their clinical trials. The negative assessment of the Oxford vaccine is now crumbling, Ludwig said.

Janosch Dahmen, Greens party member of parliament, told The BMJ, "The fact that more than one million doses of the Oxford AstraZeneca vaccine have not been used in Germany to date is a scandal." Dahmen, a trained physician, said that the communication by the German government and STIKO has been "very poor," and called for an information campaign. "It must become clear that all available vaccines are safe, effective, and the only available means to shorten the pandemic by years," he said. Anyone who refuses to be vaccinated with the Oxford AstraZeneca vaccine should lose the vaccination appointment and then "have to get back in line," he added.

Robert Kock Institut. Digitales Impfquotenmonitoring zur covid-19-Impfung. [German] www.rki.de/DE/Content/InfAZ/N/Neuartiges_Coronavirus/Daten/Impfquoten-Tab.html.

2 Boytchev H. Why did a German newspaper insist the Oxford AstraZeneca vaccine was inefficacious for older people-without evidence?BMJ 2021;372:n414. doi: 10.1136/bmj.n414 pmid: 33579678

3 Montgomery gegen Astra-Zeneca-Impfung bei medizinischem Personal. [German] www.handelsblatt.com/dpa/konjunktur/pandemie-montgomerygegen-astra-zeneca-impfung-bei-medizinischem-personal/26921564.html?ticket=ST-9435137-7DCnEtzbpJbelq1CJLdZ-ap1.

4 AstraZeneca. Kommt bald neue Empfehlung? [German] ZDFmediathek. 26 February 2021. www.zdf.de/nachrichten/heute-journal/astrazeneca-kommtbald-neue-empfehlung-100.html. 